\title{
Indicators of inflammation in the diagnosis of mastitis
}

\author{
Satu PYÖRÄLÄ* \\ University of Helsinki, Faculty of Veterinary Medicine, Department of Clinical Veterinary Sciences, \\ Saari Unit, 04920 Saarentaus, Finland
}

(Received 9 October 2002, accepted 31 January 2003)

\begin{abstract}
Mastitis affects the quality of milk and is a potential health risk for the other cows. In a well managed dairy herd, in addition to clinical mastitis, subclinical mastitis should be efficiently detected. Bacteriological sampling is not feasible as a routine test to identify subclinical mastitis, and indirect tests of mastitis are more suitable for selecting cows with intramammary infections for subsequent bacteriological sampling. Mastitis affects the composition of milk, and the degree of changes depends on the infecting agent and the inflammatory response. Indicators of inflammation in the milk which can be determined using rapid, reliable and easy routine techniques, can be used for the early detection of mastitis. The measuring of the somatic cell count in milk is the standard method, but the analysis technique is problematic for routine use in herds. The most promising parameters for monitoring subclinical mastitis are milk N-acetyl- $\beta$-D-glucosaminidase activity, lactose, and electrical conductivity along with some other indicators such as optical and milk flow measurements, preferably with an inter-quarter evaluation included in the test. Acute phase proteins, haptoglobin and serum amyloid A, are also potential candidates for mastitis monitoring. New mastitis detection systems which can be adapted into on-line use are urgently needed, since dairy units are growing bigger and automatic milking systems are being taken into use.
\end{abstract}

mastitis / indicator of inflammation / somatic cell count / NAGase / electrical conductivity

Table of contents

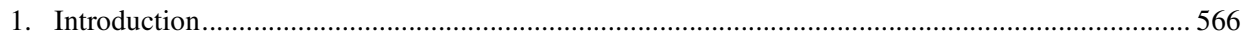

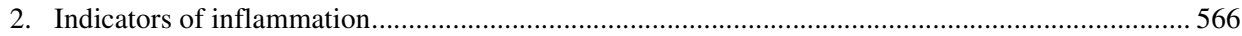

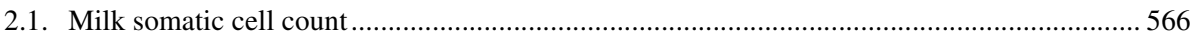

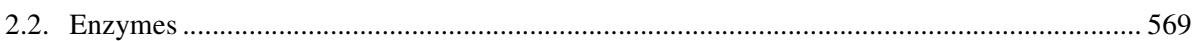

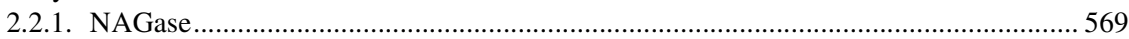

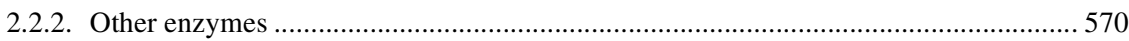

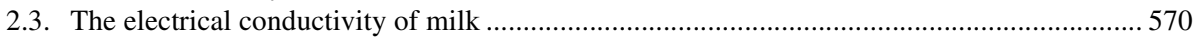

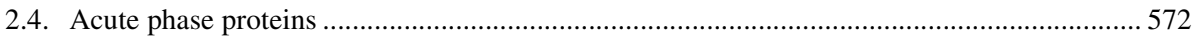

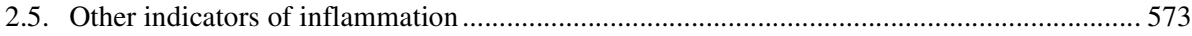

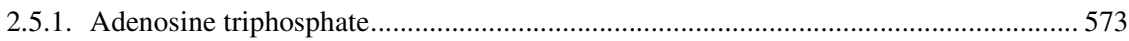

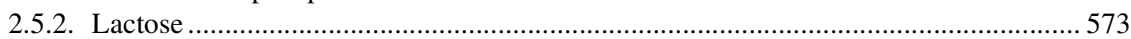

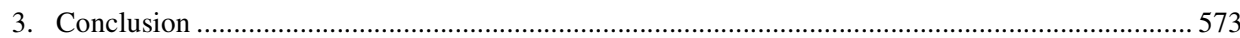

\footnotetext{
* Corresponding author: satu.pyorala@helsinki.fi
} 


\section{INTRODUCTION}

There are three levels where the detection of mastitis and assessment of milk quality is required: individual cow level in the herd, a more large scale testing for the bulk milk, and finally, testing of milk supplies in the dairy plant. This paper focuses on the individual cow level, where cows with mastitic quarters should be detected. The current EU Hygiene Directive 89/362/ EEC sets the following requirement: before milking of the individual cow the milker must inspect the appearance of the milk. If any physical abnormality is detected, milk from the cow must be withheld from delivery. In traditional milking systems inspection is possible, but in the automatic milking system (AMS), this requirement cannot be met and must be replaced with an automatic mastitis detection system. A mastitis detection system with a sufficient discriminatory capacity and applicable for on-line measurement is urgently needed for AMS, but could also be useful in units with traditional milking.

Mastitis affects the milk quality and production of the cow and may spread to the other cows in the herd. Clinical mastitis is easy to detect but also cows with subclinical mastitis should be identified. Bacteriological sampling is not feasible as a routine test to detect mastitis. Tests for indicators of inflammation are therefore necessary as screening tests to identify quarters with intramammary infections (IMI) and to select cows for subsequent bacteriological sampling [57]. Mastitis changes the composition of milk, and the extent to which various compositional changes occur depends on the inflammatory response [32, 34]. The degree of changes depend on the pathogenicity of the mastitis causing bacteria and the amount of affected tissue in the gland; especially the affected epithelial area. The main changes in the udder include (1) leaking of ions, proteins and enzymes from the blood into the milk due to an increased permeability, (2) invasion of phagocyting cells into the milk compart- ment, and (3) a decrease of the synthetic capacity of the gland, resulting in decreased concentrations of certain milk constituents [34]. The affected quarter may also produce substances related to the inflammatory reaction such as acute phase proteins [12]. Some of the compositional changes are more marked than others (Tab. I) and they are potentially useful to detect mastitis. The golden standard to measure inflammation is the cytological investigation; milk somatic cell count (SCC), and other methods are compared with SCC [19]. The diagnosis of mastitis according to the International Dairy Federation (IDF) recommendations is based on the SCC and microbiological status of the quarter $[23,28]$. The final definition of mastitis with agreed thresholds is still under debate; suggestions for definitions can be seen in Table II.

At present, the only indirect mastitis tests which can be used as the "cow side" tests are the Californian Mastitis Test (CMT) and measuring the electrical conductivity (EC) of the milk using a hand-held meter. The misclassification of these tests may range between $25-50 \%$, but it is evident that CMT is superior over the handheld EC meters [57].

\section{INDICATORS OF INFLAMMATION}

\subsection{Milk somatic cell count}

The somatic cells present in the milk of a healthy cow belong mainly to the macrophages (66-88\%); in addition there are neutrophils, and epithelial and mononuclear cells $[47,58]$. The proportion of neutrophils is only $1-11 \%$ in a healthy quarter but increases up to $90 \%$ and more in a quarter with IMI [58]. The proportion of neutrophils as the percentage of the SCC has been proposed as a mastitis indicator [20]. It has been suggested that instead of total SCC, differential cell counting should 
Table I. Main changes in the production and composition of milk caused by mastitis [20, 32, 34].

\begin{tabular}{lccc}
\hline Decrease & Degree of change & Increase & Degree of change \\
\hline Quarter milk yield & $-(--)$ & Somatic cell count & +++ \\
Dry matter & - & Whey proteins & +++ \\
Lactose & - & Bovine serum albumin & + \\
Fat & - & Immunoglobulins & +++ \\
Long-chained fatty acids & - & K casein & +++ \\
Total casein & -- & Proteose peptones & ++ \\
$\alpha_{\text {S1 casein }}$ casein & -- & Free fatty acids & ++ \\
$\beta$ cactalbumin & --- & Short-chained fatty acids & + \\
$\alpha$ lacta & Sodium & ++ \\
$\beta$ lactoglobulin & - & Chloride & ++ \\
Calcium & --- & Lactate & +++ \\
Magnesium & --- & Enzyme activity & \\
Phosphorus & --- & Lipase & ++ \\
Zinc & -- & Lysozyme & +++ \\
Potassium & - & NAGase & +++ \\
& - & $\beta$ glucuronidase & +++ \\
& & Plasmin & +++ \\
\hline
\end{tabular}

Table II. Criteria for diagnosis of mastitis, based on the results from the quarter milk sample [19,28].

\begin{tabular}{|c|c|c|}
\hline \multicolumn{2}{|r|}{ Result from the milk sample } & \multirow[t]{2}{*}{ Diagnosis } \\
\hline Bacterial growth & Inflammation (e.g. SCC over 200000 cells $/ \mathrm{mL}$ ) & \\
\hline Yes & No & $\begin{array}{c}\text { Latent infection }{ }^{\mathrm{a}} \text { or } \\
\text { Presence of bacterial growth }\end{array}$ \\
\hline No & Yes & $\begin{array}{c}\text { Non-specific mastitis }{ }^{\mathrm{a}} \\
\text { Mastitis }^{\mathrm{b}}\end{array}$ \\
\hline Yes & Yes & Mastitis \\
\hline
\end{tabular}

a International Dairy Federation definition [28].

b Alternative definition (National Veterinary and Food Research Institute, Finland).

be performed which would provide more information about the health status of a quarter [47], but this approach has not been widely adapted and is not feasible in practical conditions.

Milk SCC has been used extensively as an indicator of IMI since the nineteen-sixties. SCC has been included as a component of the definition of mastitis (Tab. II), and the original limit for SCC of a healthy quarter is 500000 cells $/ \mathrm{mL}$ [28]. The threshold levels for SCC were based on a population mean plus two times standard deviation for one measurement of the foremilk from an individual quarter. The definition was a guide for diagnosis, even though $50 \%$ of 
truly infected quarters could at any time have a cell count less than the break-point of 500000 cells $/ \mathrm{mL}$ [28]. The terms latent infection and non-specific mastitis have been in use since that date (Tab. II), but are not considered to be fully satisfactory. The threshold of 500000 cells $/ \mathrm{mL}$ for a quarter has not been relevant for a long time. The sensitivity and specificity of using a lower threshold of SCC, 200000 cells $/ \mathrm{mL}$, for IMI has been evaluated in several studies; the reported sensitivities range from 73$89 \%$ and specificities from $75-85 \%$ [57]. It must be pointed out that SCC is always compared with bacteriology, and these tests can never completely agree. Recently an SCC limit of 100000 cells $/ \mathrm{mL}$ was suggested for a healthy quarter [23]. The SCC for the composite milk from a cow should not exceed 100000 cells $/ \mathrm{mL}$, which has been confirmed in publications [35]. It is evident that a healthy quarter with no bacterial growth contains less than 100000 cells $/ \mathrm{mL}$, and if the cell count exceeds 200000 cells $/ \mathrm{mL}$, the quarter is very likely to be infected. It is not relevant if the bacteria are minor or major pathogens, even though the so-called minor pathogens cause less elevation in the SCC $[8,23]$. Use of consecutive SCC records for individual cows which are available in many countries makes the evaluation of the udder health status of the cow more reliable.

Lactation stage affects the SCC so that immediately after parturition SCC is high, but decreases fast to the normal level within 4-5 days after calving [2]. Towards the end of the lactation period, SCC increases slightly [5, 41]. According to more recent studies, the physiological effects affect very little the SCC of truly healthy cows [36]. It was shown by Barkema et al. [2] that SCC decreases to a low level within 3 days in healthy quarters but remains high in the infected ones; thus quarter SCC can be used early post partum to detect new IMIs. In a study on newly calved cows, using a threshold of 100000 cells $/ \mathrm{mL}$ for quarter milk samples the accuracy for mastitis detection was the best on day 5 post-calving: using this sampling scheme the sensitivity to identify quarters infected with major pathogens was $66.2 \%$ and that for minor pathogens $51.4 \%$ [60].

Milking frequency also affects milk SCC. A shift from a two times a day to three times a day milking was clearly shown to decrease bulk milk SCC and the proportion of high SCC cows [26]; on the contrary very short milking intervals ( $4 \mathrm{~h}$ and less) were found to increase SCC [18]. Long milking intervals increase bulk milk SCC which has been seen in connection with technical pauses in the AMS [49], and this is suggested to be due to the increased number of IMI and rise in the milk SCC of individual cows with the longest milking intervals.

In a recent paper using meta-analysis, the effect of different pathogens on quarter SCC was studied [8]. The average SCC for bacteriologically negative quarters was 68000 cells $/ \mathrm{mL}$, average SCC for quarters infected with minor pathogens was between 110000 cells $/ \mathrm{mL}$ and 150000 cells $/ \mathrm{mL}$, and that for quarters infected with major pathogens was higher than 350000 cells $/ \mathrm{mL}$. The highest mean value was found in mastitis caused by coliforms and Streptococcus uberis (over 1 million cells $/ \mathrm{mL}$ ), and the lowest in IMI caused by corynebacteria, 105000 cells $/ \mathrm{mL}$.

There are various automatic methods for somatic cell counting, and the standard method is the electro-optical Fossomaticmethod. SCC can also be estimated using CMT which is based on the DNA content of the milk; the reagent is simply a detergent and bromcresol purple is used as an indicator of $\mathrm{pH}$ [58]. The ability of CMT to identify quarters with IMI has been evaluated extensively, with variable results. CMT was studied as a tool to select cows for dry cow therapy, and was found to correctly identify $75-80 \%$ of the cows which needed the therapy, depending on the study and type of the mastitis pathogen [51]. In a recent study, CMT was compared with SCC in newly calved cows [60]. CMT was 
found to be suitable for herd monitoring programmes to detect fresh cows with IMI caused by major pathogens. CMT taken on the third day after calving using a threshold of reaction greater than zero (the CMT results were scored from zero to 3 where zero represents SCC less than 200000 cells $/ \mathrm{mL}$ ) was found to have the highest sensitivity and specificity for detecting IMI. Using this sampling scheme the sensitivities to detect IMI caused by major pathogens was $66.7 \%$ and that for minor pathogens $49.5 \%$. The best sensitivity was found in IMI due to environmental streptococci (84\%). CMT has an advantage of being very inexpensive and the only cow-side test with real-time results for selection of the quarters for subsequent bacteriological examination. However CMT is not a test for large-scale monitoring purposes unless automatised, which cannot yet be foreseen.

\subsection{Enzymes}

Many of the indigenous enzymes increase in milk during inflammation (Tab. I). The enzymes dealing with the synthesis of milk decrease and the enzymes related to inflammation increase. The enzymes originating from phagocytes increase exponentially, and they include $\mathrm{N}$-acetyl- $\beta$-D-glucosaminidase (NAGase), beta-glucuronidase and catalase. The activity of the enzymes originating from the blood also increase, for example plasminogen which then is locally activated to plasmin, a proteolytic enzyme that degrades fibrin and casein $[30,34]$.

\subsubsection{NAGase}

Lysosomal enzymes have proven to be reliable indicators of inflammation. NAGase is an intracellular, lysosomal enzyme which is released into milk from neutrophils during phagocytosis and cell lysis, and to some degree, damaged epithelial cells [33]. The major part of milk NAGase activity is in the cellular compartment and thus freezing and thawing of the samples are used for a maximal release of activity [31]. NAGase activity has in several studies been found to reliably detect IMI with mastitis pathogens $[32,39]$. Milk NAGase activity correlates very closely with SCC $[32,40]$. It accurately reflects the degree of inflammation so that in mastitis caused by major pathogens, milk NAGase level is significantly higher than in mastitis due to minor pathogens $[38,40]$. The capacity of milk NAGase activity to detect subclinical mastitis was tested considering SCC above 400000 cells $/ \mathrm{mL}$ as a positive reference for mastitis [1]. It was concluded that the test performed well since it gave an average of $17 \%$ false positive and $2 \%$ false negative diagnoses. Milk NAGase activity is high in early lactation and slightly increases towards the end of lactation [39, 40]. In healthy quarters however it has already reached the normal level by the fifth day after calving [52].

A fluorometric NAGase assay based on microtitration tray technology has been developed [39]. The method has a high capacity and is based on a within test quarter comparison, where other quarters are compared with the lowest value of the particular cow. The method has a potential for herd monitoring, but unfortunately no test is commercially available. Preliminary results from an electrochemical method for determination of milk NAGase activity has been published [42], but further research is needed to apply this system alone or in combination with other parameters to automatic detection of mastitis.

Milk NAGase activity was compared with SCC to monitor recovery after an antibiotic treatment of mastitis [53], and was found suitable for supplementing bacteriological examination in the assessment of a cure. Thresholds should be adjusted, depending on the causing bacterial agent, since the rate of the alleviation of the inflammatory reaction varies. The highest sensitivities and specificities to predict a bacterial cure of mastitis were found for mastitis caused by Staphylococcus aureus; in mastitis due to coagulase-negative 


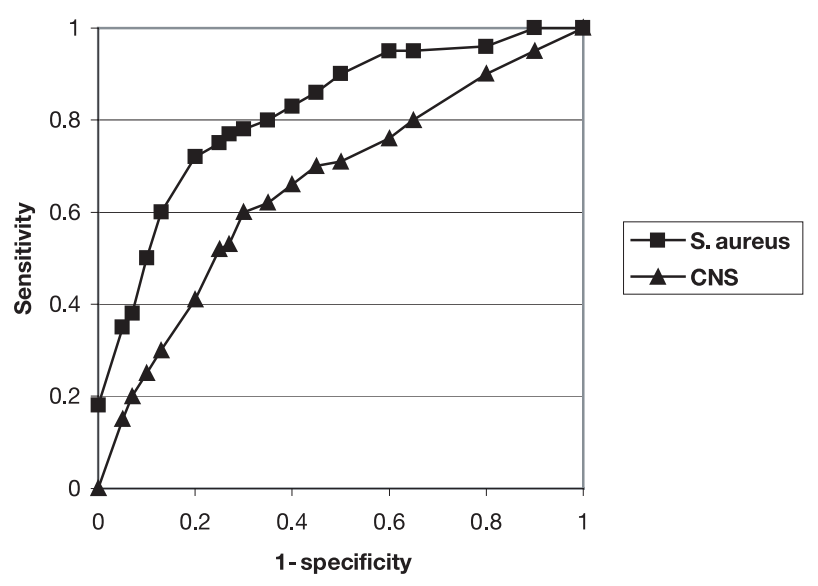

Figure 1. Receiver operating characteristics (ROC) analysis for milk NAGase activity to assess the capacity of the test to predict the cure of cows treated for clinical mastitis caused by Staphylococcus aureus or coagulase-negative staphylococci [53]. Milk samples for NAGase activity determination were taken three weeks post-treatment, and the results of bacteriological culture from the same samples were used as a reference method. In the ROC analysis, sensitivity is plotted as a function of 1-specificity (the false positive rate) at each cut-off point. The higher the sensitivity and specificity at each cut-off point are, the closer the curve will approach the upper left corner of the graph and the greater the AUC (area under the curve) will be. An AUC of 0.5 represents a test with no diagnostic value.

staphylococci the discriminatory capacity of the tests remained low (Fig. 1).

\subsubsection{Other enzymes}

In his review article Kitchen [32] listed many enzymes which increase in mastitis and could have potential in mastitis detection: different lipases, esterases, phosphatases, lactate dehydrogenase, etc. No evidence has appeared for their usefulness as screening tests for subclinical mastitis. The concentration of the proteolytic enzyme plasmin has also been shown to increase in mastitis [30, 50]. Plasminogen leaks from the blood into milk and is converted to plasmin. Plasmin could in theory be used as a mastitis indicator, but the concentration of plasmin in milk varies also due to physiological and environmental factors [50]. Milk plasmin activity is positively correlated with SCC. An increase of SCC from $100000 / \mathrm{mL}$ to $1300000 / \mathrm{mL}$ was associated with a 2.3 fold increase in plasmin activity [50]. A fluorometric method for the determination of plasmin has been developed and also adapted to the microplate technique [40], but the method is not applicable for large scale use. There is no information about the sensitivity or specificity of milk plasmin to detect IMI caused by different pathogens. No proposals have been made to introduce plasmin for use as a mastitis detector.

\subsection{The electrical conductivity of milk}

Measuring EC of milk to detect mastitis is based on the ionic changes which occur during inflammation, since the sodium and chloride concentrations increase in milk $[32,34]$. Also the change in $\mathrm{pH}$ and decrease of fat affect EC. Electrical conductivity has a high correlation with SCC in foremilk. Electrical conductivity measuring can be converted into a computer readable signal and therefore this method is easily applicable to on-line automatic 
monitoring of udder health and can be installed in milking machines. Mastitis is not the only factor affecting the ionic content of milk, and non-mastitis related variation in EC is a major drawback to the diagnostic value of EC [21]. As many other mastitis parameters, conductivity is also influenced by the age of the cow and the stage of lactation [44]. The use of EC as a diagnostic method for the identification of subclinical mastitis has been studied for a long time with variable results [20, 29]. A positive correlation was found between SCC and EC (0.51-0.75) and the use of inter quarter ratios enhances the evaluation $[19,29]$. In general no attention has been paid to the pathogen involved in the mastitis, but recently the effect of different pathogens was studied [38]. In general, the quarter values from infected quarters were significantly higher than those from uninfected quarters. Quarters infected with S. aureus and Streptococcus agalactiae had lower conductivity values than quarters infected with environmental streptococci. The values did not always differ significantly from the uninfected quarter values when lactation day and the age of the cow were included in the model. The conclusion from this study is that the EC of milk as a component of an early warning system for udder health monitoring is only suitable when all influencing factors are taken into consideration and the measured values are corrected accordingly.

EC was shown to reliably predict clinical mastitis in experimental Str. uberis mastitis model [24]. In one study [37], all clinical mastitis cases were found (threshold 500000 cells $/ \mathrm{mL}$ plus positive bacteriology) but only $50 \%$ from the subclinical cases (> 200000 cells $/ \mathrm{mL}$ ). In another study [45] when lactation stage, milk yield and parity were taken into consideration, EC showed a sensitivity of $55 \%$ to detect subclinical mastitis (threshold $>500000$ or one million cells $/ \mathrm{mL}$ ). For test accuracy it is best to use foremilk. Experts of IDF [21] have recently evaluated EC using a metaanalysis, and they concluded that EC does not perform well in the detection of either subclinical or clinical mastitis (Tab. III). However an automatic detection model was recently introduced [6] where timeseries models for two variables (milk yield and EC) were used, and much better results in mastitis detection were obtained. In the AMS EC is normally used together with milk yield and flow rate, and colour and temperature of the milk $[6,54]$. The manufacturers do not generally provide the exact algorithms used in their system, which makes the evaluation of different detection systems difficult.

Hand-held EC meters are available in different countries. The diagnostic accuracy of one device was recently evaluated [43]. It was found that at the cut-off point recommended by the manufacturer, $71 \%$ of the test-positive samples were bacteriologically negative and major mastitis bacteria were isolated from $11 \%$ of the testnegative samples. Other published reports give similar results and it can be concluded that the predictive value of the method is generally poor [21, 57]. Other screening

Table III. The diagnostic capacity of milk electrical conductivity to predict clinical and subclinical mastitis [21].

\begin{tabular}{lccccc}
\hline Diagnosis & $\begin{array}{c}\text { Criteria for } \\
\text { diagnosis }\end{array}$ & $\begin{array}{c}\text { Sensitivity } \\
(\%)\end{array}$ & $\begin{array}{c}\text { Specificity } \\
(\%)\end{array}$ & $\begin{array}{c}\text { Positive predictive } \\
\text { value }(\%)\end{array}$ & $\begin{array}{c}\text { Negative predictive } \\
\text { value }(\%)\end{array}$ \\
\hline Clinical mastitis & Signs & 68 & 82 & 58 & 82 \\
Subclinical mastitis & SCC & 68 & 88 & 72 & 85 \\
Subclinical mastitis & IMI & 61 & 66 & 55 & 70 \\
\hline
\end{tabular}


tests such as CMT and individual SCC values are clearly more useful than hand-held EC meters.

A comparison of EC values between the quarters of the cow should reduce the intrinsic variation. The use of an interquarter evaluation has been reported to improve the sensitivity and specificity of EC [44], and is currently the recommended way to use this test. It is, however, evident that measuring EC alone is not sufficient for detecting IMI.

\subsection{Acute phase proteins}

An acute phase reaction causes the release of many proteins synthesised by the liver. These proteins that increase are considered positive acute phase proteins, or simply acute phase proteins $[48,55]$. In cattle, most sensitive acute phase proteins are haptoglobin and serum amyloid A (SAA), which show a substantial rise in the response to acute inflammation, and $\alpha_{1}$-acid glycoprotein, which also increases in chronic conditions [11, 62]. Haptoglobin and SAA are major acute phase proteins in cows, the concentration of which in serum can increase over 100-fold [4,11]; $\alpha_{1}$-acid glycoprotein is a moderate acute phase protein, which has a low relative rise, reacts slowly and indicates more chronic inflammation $[11,12]$. The concentration of haptoglobin in the serum has been shown to dramatically increase in cows with experimental and spontaneous coliform mastitis $[25,46]$. Methods have become available to measure serum haptoglobin with a biochemical assay and SAA with an immunoassay [12].

The first acute phase proteins measured from milk and used as indicators of inflammation are bovine serum albumin and $\alpha_{1}$-trypsin inhibitor [15, 58, 59]. Serum albumin can be measured using the radial immunodiffusion technique, in which the antibody is within the agar layer. The method is time consuming and not practical for automatisation; in addition the dis- criminatory capacity of this protein is not high. The $\alpha_{1}$-trypsin inhibitor can be quantified indirectly by measuring the trypsininhibitory capacity of the milk. In the method, the remaining trypsin activity is measured using colorimetric or fluorometric substrates. A test to detect mastitis based on microtitration tray technology has been developed [59].

More research has recently been focused on the determination of acute phase proteins in milk. In the study by Eckersall et al. [12], haptoglobin and SAA were measured from milk and serum, and compared as tests to detect IMI. A significant correlation was found between the concentrations of haptoglobin in the serum and milk, but the concentrations of SAA in the serum and milk were not related. No correlation was found between haptoglobin and serum amyloid A levels in milk. Serum amyloid A could distinguish between mild and moderate mastitis. Extrahepatic synthesis of acute phase proteins has been reported [55], and SAA may also be produced locally in the mammary gland [12]. This was recently supported by data from an experimental Escherichia coli mastitis model where concentrations of SAA were two-fold higher in the milk as compared with the levels in serum (Lehtolainen, unpublished results). Using a threshold value of $0.02 \mathrm{mg} / \mathrm{mL}$ for milk haptoglobin and $0.55 \mu \mathrm{g} / \mathrm{mL}$ for milk SAA, both tests had a high specificity $(100 \%)$ with no false positive results, and a reasonable sensitivity ( 86 and 93 ) for the diagnosis of mastitis [12]. One advantage is that these proteins are not present at all in healthy cows. The assay for SAA has the disadvantage of being an ELISA test, whereas the biochemical assay for haptoglobin is faster and may be more easily adapted to automatic analysis systems. An ELISA for bovine haptoglobin is also available, which can detect lower concentrations and is less sensitive for disturbing factors than the biochemical test.

The $\mathrm{C}$-reactive protein is not regarded as an acute phase protein in cattle [11], but has 
been tested as an indicator for mastitis. The concentration of C-reactive protein was shown to increase in bovine milk during mastitis [61]; an ELISA assay was developed to analyse the C-reactive protein. The capacity of the milk C-reactive protein to distinguish between healthy and mastitic quarters was found to be poor [22], and the correlation between the concentration of the C-reactive protein in milk and SCC was low $(r=0.32)$. It seems that the C-reactive protein does not have the best potential to be used in the detection of mastitis.

\subsection{Other indicators of inflammation}

\subsubsection{Adenosine triphosphate}

Adenosine triphosphate (ATP) is present in all living cells and thus also in somatic cells of the milk. ATP in milk is both of cellular and extracellular origin [56]. ATP can be measured using a bioluminescence technique where the enzyme-co-enzyme complex luciferase and luciferin is used. ATP has a strong positive correlation with SCC and has been considered as an alternative to SCC as an indicator of mastitis [13]. Parity and stage of lactation were shown to have significant effects on milk ATP content similar to those on SCC [13]. Bioluminescence is currently used mostly to monitor bacterial contamination in different food production processes [14]. At present there are no suggestions to use ATP for mastitis monitoring.

\subsubsection{Lactose}

Mastitis results in tissue damage and the decreased synthetic ability of the enzyme systems of the secretory cells, and the biosynthesis of lactose is also decreased. There is little variation within lactation and from one lactation to the next, which is a benefit for a parameter of mastitis [32]. The lactose concentration of milk could be used as an indicator of mastitis, since it clearly decreases during inflammation. The per- cent decrease is, however, relatively small, which compromises the use of lactose to detect mastitis [3, 20]. The association between lactose, SCC and mastitis has been studied already since the nineteen-eighties and the results are reviewed by Kitchen [32]. Berning and Shook [3] compared SCC, NAGase and lactose, and found out that $\log$ NAGase and SCC were most responsive to changes in infection status, but lactose did not perform so well. A positive argument is that analysis methods for lactose are available on a large scale since lactose is monitored routinely as part of the herd milk recording systems along with fat and protein. Recently lactose was proposed to be one of the most useful markers of mastitis for the future use with a proposed threshold value of $4.7 \%[19,20]$. However more practical experience is needed on the usefulness of lactose as a screening indicator.

\section{CONCLUSION}

When comparing the diagnostic tests, correlation analysis is used to tell whether two tests e.g. SCC and lactose are related. The problem is that the changes of the inflammatory parameters are not necessarily parallel during the course of inflammation [58]. Proteins leaking from the blood correlate well because the mechanism is similar. The choice of the threshold value for each test is of crucial importance: the threshold level affects the proportion of correctly and incorrectly classified samples $[16,57,58]$. Herd mastitis prevalence affects the predictive values of the tests, as shown by Dohoo and Leslie [10]. Likelihood ratios based on the ranges of the test (e.g. SCC) results, to predict the probability of subclinical mastitis eliminate the need to set a strict threshold and incorporate information on herd prevalence; this methodology used for SCC was recently described in detail [9].

In a recent study [19], six different milk parameters were measured from the same 


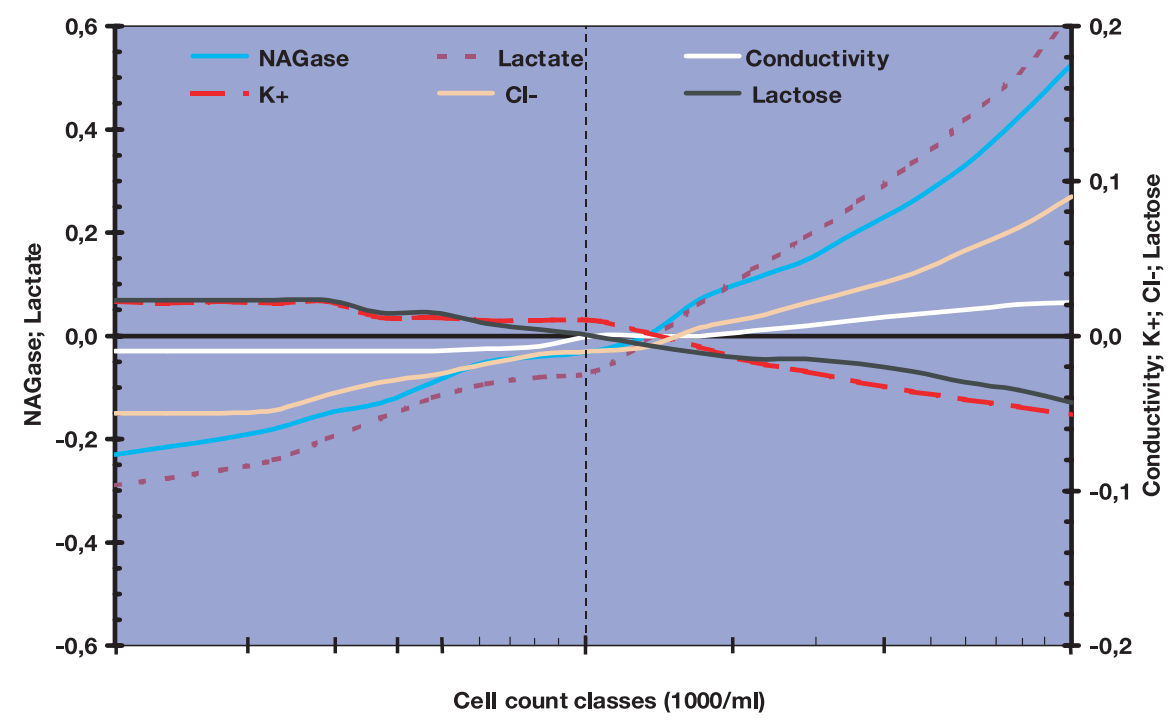

Figure 2. Mean deviation (in $\log 10$ ) of selected milk constituents from the overall means in relation to cell count classes. The zero line is a reference of a healthy quarter for all components across the somatic cell count ranges. Above the cell count of 100000 cells $/ \mathrm{mL}$ all tested milk components differ significantly from the physiological norm (reproduced from [19] with permission).

quarter milk samples and were compared with SCC. The parameters studied were milk lactate, lactose, NAGase, potassium, chloride, and conductivity. Figure 2 shows the deviation of the milk components in the different SCC ranges. A distinct slope change was seen for all the tested milk components when SCC exceeded 100000 cells/ $\mathrm{mL}$. It was suggested that the physiological norm is around 100000 cells $/ \mathrm{mL}$. Above this level, the milk components will differ significantly from the physiological norm; thus the results support the proposal of taking 100000 cells/mL as the threshold value for quarter SCC. Milk lactate, NAGase and chloride showed the biggest deviation from the reference level representing healthy quarters.

Estimates for the diagnostic sensitivity and specificity may vary in populations, and an epidemiological approach should be used for validation of diagnostic tests [16]. Receiver-operating characteristics (ROC) can be used for the evaluation of diagnostic tests [17]: in this analysis all possible combinations of sensitivity and specificity achieved by changing the cut-off value of the test can be summarized using a single parameter, the area under the ROC curve. The problem regarding mastitis is that indirect tests are compared with the "golden standard", bacteriology, and mastitis does not always require the presence of infection. To the knowledge of the author, ROC analysis has only twice been used to evaluate a test to detect mastitis [7,53]. Figure 1 shows the nonparametric ROC analysis for milk NAGase activity after treatment of mastitis caused by S. aureus and coagulase-negative staphylococci [53].

In mastitis detection, the sensitivity of the method is of particular importance. SCC is the basic parameter but it is compromised by the analysis technique which is difficult to adapt to on-line use. The capacities of some of the most promising tests to detect IMI and their proposed threshold limits as compared with the SCC 
Table IV. Capacity of different milk components as diagnostic tests to detect subclinical mastitis [35].

\begin{tabular}{|c|c|c|c|c|c|}
\hline Parameter & $\begin{array}{l}\text { Foremilk (FM) } \\
\text { or Composite } \\
\text { milk (CM) }\end{array}$ & $\begin{array}{c}\text { Threshold based } \\
\text { on SCC limit of } \\
100000 / \mathrm{mL}\end{array}$ & $\begin{array}{c}\text { Sensitivity } \\
(\%)\end{array}$ & $\begin{array}{c}\text { Specificity } \\
(\%)\end{array}$ & $\begin{array}{c}\text { Probability of } \\
\text { misclassification } \\
(\%)\end{array}$ \\
\hline NAGase activity & FM & $\begin{array}{c}0.42 \mathrm{nmol} \times \\
\min ^{-1} \times \mathrm{mL}^{-1}\end{array}$ & 71.7 & 79.8 & 22.3 \\
\hline Electrical conductivity & FM & $6.5 \mathrm{mS} / \mathrm{cm}$ & 35.6 & 95.1 & 19.9 \\
\hline Lactate & $\mathrm{CM}$ & $80 \mathrm{mmol} / \mathrm{L}$ & 43.3 & 94.7 & 22.9 \\
\hline Lactose & $\mathrm{CM}$ & $4.7 \%$ & 60.8 & 80.6 & 26.1 \\
\hline
\end{tabular}

a Probability of misclassification = percentage of false positive and false negative diagnoses.

of 100000 cells $/ \mathrm{mL}$ are shown in Table IV [35]. Probably milk NAGase activity in foremilk and lactose in composite milk could be considered the best candidates at the moment. The use of milk NAGase activity as a mastitis indicator is supported by abundant literature for more than twenty years and the influence of the physiological and pathological factors on milk NAGase levels are well known. Among acute phase proteins, haptoglobin and SAA are the most potential candidates, but there is hardly any experience about their use in mastitis detection. These parameters cannot yet be measured on-line automatically, but techniques are to be developed for this in the future.

None of the automatic detection systems can at present reliably detect subclinically infected quarters or even visually abnormal milk [54]. The detection of subclinical mastitis is not satisfactory in any models, and false alerts are so common that farmers easily stop using the automatic detection systems [27]. Electrical conductivity does not perform well enough alone and should be supplemented with other parameters such as milk flow characteristics, milk yield, temperature, or optical properties of the milk. Quarter milking systems offer better possibility for measuring quarter-specific data and the analysis of quarter milk composition changes for the early detection of mastitis [20]. Selection of udder quarters for subsequent bacteriology should be effective and economical. Diagnostic accuracy can be improved by considering the physiological confounding factors, by application specific epidemiological approach [16] and then optimising the thresholds for testing [9].

\section{REFERENCES}

[1] Ball H.J., Greer D., N-acetyl- $\beta$-D-glucosaminidase test for screening milk samples for subclinical mastitis, Vet. Rec. 129 (1991) 507-509.

[2] Barkema H.W., Deluyker H.A., Schukken Y.H., Lam T.J.G.M., Quarter-milk somatic cell count at calving and at the first six milkings after calving, Prev. Vet. Med. 38 (1999) $1-9$.

[3] Berning L.M., Shook G.E., Prediction of mastitis using milk somatic cell count, $N$-acetyl- $\beta$-D-glucosaminidase, and lactose, J. Dairy Sci. 75 (1992) 1840-1848.

[4] Boosman R., Niewold Th.A., Mutsaers C.W.A.A.M., Gruys E., Serum amyloid A concentrations in cows given endotoxin as acute-phase stimulant, Am. J. Vet. Res. 50 (1989) 1690-1694.

[5] Brolund L., Cell counts in bovine milk: causes of variation and applicability for diagnosis of subclinical mastitis, Acta Vet. Scand. 80 Suppl. (1985) 1-123.

[6] de Mol R.M., Ouweltjes W., Detection model for mastitis in cows milked in an automatic milking system, Prev. Vet. Med. 49 (2001) 71-82. 
[7] Detilleux J., Arendt J., Lomba F., Leroy P., Methods for estimating areas under receiver-operating characteristic curves: illustration with somatic-cell scores in subclinical intramammary infections, Prev. Vet. Med. 41 (1999) 75-88.

[8] Djabri B., Bareille N., Beaudeau F., Seegers H., Quarter milk somatic cell count in infected dairy cows: a meta-analysis, Vet. Res. 33 (2002) 335-357.

[9] Dohoo I.R., Setting SCC cutpoints for cow and herd interpretation, in: 40th Annual Meeting of National Mastitis Council, Reno, USA, February 11-14, 2001, pp. 10-18.

[10] Dohoo I.R., Leslie K.E., Evaluation of changes in somatic cell counts as indicators of new intramammary infections, Prev. Vet. Med. 10 (1991) 225-237.

[11] Eckersall P.D., Conner J.G., Bovine and canine acute phase proteins, Vet. Res. Commun. 12 (1988) 169-178.

[12] Eckersall P., Young F.J., Mc Comb C., Hogarth C.J., Safi S., Weber A., McDonald T., Nolan A.M., Fitzpatrick J.L., Acute phase proteins in serum and milk from dairy cows with clinical mastitis, Vet. Rec. 148 (2001) $35-41$.

[13] Emanuelson U., Olsson T., Mattila T., Åström G., Holmberg O., Effects of parity and stage of lactation on adenosine triphosphate, somatic cell count and antitrypsin content in cow's milk, J. Dairy Res. 55 (1988) 49-55.

[14] Finger R., Sischo W.M., Bioluminescence as a technique to evaluate udder preparation, J. Dairy Sci. 84 (2001) 818-823.

[15] Giesecke W.H., Viljoen M.H., The diagnosis of subclinical mastitis in lactating cows: a comparison of cytological methods and a monovalent radial immunodiffusion test, Onderstepoort J. Vet. Res. 41 (1974) 51-74.

[16] Greiner M., Gardner I.A., Epidemiological issues in the validation of veterinary diagnostic tests, Prev. Vet. Med. 45 (2000) 3-22.

[17] Greiner M., Pfeiffer D., Smith R.D., Principles and practical application of the receiveroperating characteristics analysis for diagnostic tests, Prev. Vet. Med. 45 (2000) 23-41.

[18] Hamann J., Changes in milk somatic cell count with regard to the milking process and the milking frequency - preliminary report, IDF Mastitis Newsletter 24 (2001) 5-6.

[19] Hamann J., Milk quality and udder health in relation to modern milking, in: Recent developments and perspectives in bovine medi- cine, XXII World Buiatrics Congress, Hannover, August 18-23, 2002, pp. 334-345.

[20] Hamann J., Krömker V., Potential of specific milk composition variables for cow health management, Livest. Prod. Sci. 48 (1997) 201-208.

[21] Hamann J., Zecconi A., Evaluation of the electrical conductivity of milk as a mastitis indicator, in: IDF bulletin 334, International Dairy Federation, Brussels, Belgium, 1998.

[22] Hamann J., Kruger M., Kretschmar M., Nipp B., Gyodi P., C-reactive protein in milk of healthy and subclinically diseased bovine udder quarters, Milchwissenschaft 52 (1997) $546-550$.

[23] Hillerton J.E., Redefining mastitis based on somatic cell count, IDF Bulletin 345 (1999) 4-6.

[24] Hillerton J.E., Semmens J.E., Comparison of treatment of mastitis by oxytocin or antibiotics following detection according to changes in milk electrical conductivity prior to visible signs, J. Dairy Sci. 82 (1999) 93-96.

[25] Hirvonen J., Eklund K., Teppo A.M., Huszenicza G., Kulcsar M., Saloniemi H., Pyörälä S., Acute phase response in dairy cows with experimentally induced Escherichia coli mastitis, Acta Vet. Scand. 40 (1999) 35-46.

[26] Hogeveen H., Miltenburg J.D., den Hollander S., Frankena K., Milking three times a day and its effect on udder health and production, IDF Mastitis Newsletter 24 (2001) 7 .

[27] Hovinen M., Kasanen I., Pyörälä S., Monitoring of udder health in automatic milking, in: First American Conference on Robotic milking, Toronto, Canada, 2002, pp. 71-74.

[28] International Dairy Federation, A monograph of bovine mastitis, 1971

[29] Jensen N.E., Knudsen K., Inter-quarter comparison of markers of subclinical mastitis: somatic cell count, electrical conductivity, $\mathrm{N}$-acetyl- $\beta$-D-glucosaminidase and antitrypsin, J. Dairy Res. 58 (1991) 389-399.

[30] Kaartinen L., Sandholm M., Regulation of plasmin activation in mastitic milk. Correlation with inflammatory markers and growth of Streptococcus agalactiae, J. Vet. Med. B 34 (1986) 42-50.

[31] Kaartinen L., Kuosa P.L., Veijalainen K., Sandholm M., Compartmentalization of milk $\mathrm{N}$-acetyl- $\beta$-D-glucosaminidase (NAGase) by storage. Freezing and thawing, detergent and using cell stimulants, J. Vet. Med. B. 35 (1988) 408-414. 
[32] Kitchen B., Review of the progress of dairy science: Bovine mastitis: Milk compositional changes and related diagnostic tests, J. Dairy Res. 48 (1981) 167-188.

[33] Kitchen B., Kwee W.S., Middleton G., Andrews R.J., Relationship between the level of $\mathrm{N}$-acetyl- $\beta$-D-glucosaminidase (NAGase) in bovine milk and the presence of mastitis pathogens, J. Dairy Res. 51 (1984) 11-16.

[34] Korhonen H., Kaartinen L., Changes in the composition of milk induced by mastitis, in: Sandholm M., Honkanen-Buzalski T., Kaartinen L., Pyörälä S. (Eds.), The bovine udder and mastitis, Gummerus, Jyväskylä, Finland, 1995, pp. 76-82.

[35] Krömker V., Grabowski N.T., Redetzky R., Hamann J., Detection of mastitis using selected quarter-milk parameters, in: 2nd International Symposium on Bovine Mastitis and Milk Quality, Vancouver, Canada, 2001, pp. 486-487.

[36] Laevens H., Deluyker H., Schukken Y.H., de Meulemeester L., Vandermeersch R., de Muelenaere E., de Kruif A., Influence of parity and stage of lactation on the somatic cell count in bacteriologically negative cows, J. Dairy Sci. 80 (1997) 3219-3226.

[37] Maatje K., Huijsmans P.J.M., Rossing W., Hogewerf P.H., The efficacy of on-line measurement of quarter milk electrical conductivity, milk yield and milk temperature for the detection of clinical and subclinical mastitis, Livest. Prod. Sci. 30 (1992) 239-249.

[38] Mansfeld R., Mansfeld S., Santl B., Hoedemaker M., New aspects regarding the use of the milk electrical conductivity as a parameter for routine diagnostics in dairy production medicine programs, in: 2nd Int. Symposium on Bovine Mastitis and Milk Quality, Vancouver, Canada, 2001, pp. 488-489.

[39] Mattila T., Sandholm M., Antitrypsin and $\mathrm{N}$-acetyl- $\beta$-D-glucosaminidase as markers of mastitis in a herd of Ayrshire cows, Am. J. Vet. Res. 46 (1986) 2453-2456.

[40] Mattila T., Syväjärvi J., Sandholm M., Milk antitrypsin, NAGase, plasmin and bacterial replication rate in whey - effects of lactation stage, parity and daily milk yield, J. Vet. Med. B 33 (1986) 462-470.

[41] Miller R.H., Paape M.J., Effects of parity, bacteriological status, stage of lactation, and dry period on $\mathrm{N}$-acetyl- $\beta$-D-glucosaminidase activity of milk and dry secretion, J. Dairy Sci. 71 (1988) 2508-2512.

[42] Mottram T., Hart J., Pemberton R., Biosensing techniques for detecting abnormal and contaminated milk, in: Symposium on Robotic
Milking, Lelystad, The Netherlands, 17-19 August, 2000, pp. 108-113.

[43] Musser J.M.B., Anderson K.L., Caballero M., Amaya D., Maroto-Puga J., Evaluation of a hand-held electrical conductivity meter for detection of subclinical mastitis in cattle, Am. J. Vet. Res. 59 (1998) 1087-1091.

[44] Nielen M, Deluyker H., Schukken Y., Brand A., Electrical conductivity of milk: measurement, modifiers, and meta-analysis of mastitis detection performance, J. Dairy Sci. 75 (1992) 606-614.

[45] Nielen M., Schukken Y.H., Brand A., Detection of subclinical mastitis from on-line milking parlor data, J. Dairy Sci. 78 (1995) 10391049

[46] Ohtsuka H., Kudo K., Mori K., Nagai F., Hatsugay A., Tajima M., Tamura K., Hoshi F., Koiwa M., Kawamura S., Acute phase response in naturally occurring coliform mastitis, J. Vet. Med. Sci. 63 (2001) 675-678.

[47] Östensson K., Hageltorn M., Astrom G., Differential cell counting in fraction-collected milk from dairy cows, Acta vet. Scand. 29 (1988) 493-500.

[48] Pannen B.H., Robotham J.L., The acutephase response, New Horizon 3 (1995) 183197.

[49] Pettersson G., Berglund I., Husfloen A. Tukiainen R., Svennersten-Sjaunja K., in: 1st Congress on Robotic Milking, Toronto, Canada, 2002, IV, p. 55.

[50] Politis I., Ng Kwai Hang K.F., Giroux R.N., Environmental factors affecting plasmin activity in milk, J. Dairy. Sci. 72 (1989) 1713-1718.

[51] Poutrel B., Rainard P., California mastitis test guide of selective dry cow therapy, J. Dairy Sci. 64 (1981) 241-248.

[52] Pyörälä S., Kaartinen L., Milk plasmin, antitrypsin, $N$-acetyl- $\beta$-D-glucosaminidase and bacterial growth in lactoserum during the early post partum period, Acta vet. Scand. 29 (1988) 145-150.

[53] Pyörälä S., Pyörälä E., Accuracy of methods using somatic cell count and milk N-acetyl- $\beta$ D-Glucosaminidase activity in milk to assess the bacteriological cure of bovine clinical mastitis, J. Dairy Sci. 80 (1997) 2820-2825.

[54] Rasmussen M.D., Evaluation of methods for detection of abnormal milk during automatic milking, in: Symposium on Robotic Milking, Lelystad, The Netherlands, 17-19 August, 2000, p. 125. 
[55] Raynes J.G., The acute phase response, Biochem. Soc. Trans. 22 (1994) 69-74.

[56] Richardson T., McGann T.C.A., Kearney R.D., Levels and location of adenosine 5 triphosphate (ATP) in bovine milk, J. Dairy Sci. 47 (1980) 91-96.

[57] Ruegg P.L., Reinemann D.J., Milk quality and mastitis tests, Bov. Pract. 36 (2002) 4154.

[58] Sandholm M., Detection of inflammatory changes in the milk, in: Sandholm M., Honkanen-Buzalski T., Kaartinen L., Pyörälä S. (Eds.), The bovine udder and mastitis, Gummerus, Jyväskylä, Finland, 1995, pp. 89-104.

[59] Sandholm M., Honkanen-Buzalski T., Kangasniemi R., Milk trypsin-inhibitor capac- ity as an indicator of bovine mastitis - a novel principle which can be automated, J. Dairy Res. 51 (1984) 1-9.

[60] Sargeant J.M., Leslie K.E., Shirley J.E., Pulkrabek J.L., Liim G.H., Sensitivity and specificity of somatic cell count and California Mastitis Test for identifying intramammary infection in early lactation, J. Dairy Sci. 84 (2001) 2018-2024.

[61] Schrödl W., Krüger M., Hien T.T., Füldner M., Kunze R., C-reactive protein as a new parameter of mastitis, Tierärztl. Prax. 23 (1995) 337-341.

[62] Tamura K., Yatsu T., Itoh H., Motoi Y., Isolation, characterization, and quantitative measurement of serum $\alpha_{1}$-acid glycoprotein in cattle, Jpn J. Vet. Sci. 51 (1989) 987-994. 